\title{
PROPAGATION IN VITRO OF ALSTROEMERIA LIGTU HYBRID THROUGH DIRECT ORGANOGENESIS FROM LEAF BASE
}

\author{
Fardin NASRI*1 ${ }^{1}$, Seyed Najmedin MORTAZAVI ${ }^{2}$, Nasser GHADERI ${ }^{1}$, Taimoor JAVADI ${ }^{1}$ \\ ${ }^{1}$ Department of Horticultural Science, Agricultural Faculty, University of Kurdistan, Iran \\ ${ }^{2}$ Department of Horticultural Science, Agricultural Faculty, University of Zanjan, Iran \\ Received: March 19, 2013; Accepted: November 24, 2013
}

\begin{abstract}
In the present study, multiplication efficiency of Alstroemeria ligtu hybrid was investigated. Bases of the first seedling leaves grown in vitro were used as initial explants. The explants were cultured in the MS media containing 3\% sucrose, $0.7 \%$ agar at $\mathrm{pH}$ 5.8, five N6-benzylaminopurine (BAP) concentrations $\left(0,0.5,1,1.5\right.$ and $\left.2 \mathrm{mg} \cdot \mathrm{l}^{-1}\right)$ and three indole-3-butyric acid (IBA) concentrations $\left(0,0.1\right.$ and $\left.0.2 \mathrm{mg} \cdot \mathrm{l}^{-1}\right)$. The cultures were incubated at $21 \pm 2{ }^{\circ} \mathrm{C}$ under photoperiod 16/8. After three subculturings ( 3 weeks-long each) the number of rhizome, shoots, buds, leaves, and roots, length of shoots and roots were recorded. Adventitious shoots formed directly on the leaf bases without callus intervention. Their number was affected by BAP concentrations. The highest shoots number, six per explants, was obtained at $1 \mathrm{mg} \cdot \mathrm{l}^{-1}$ BAP and $0.1 \mathrm{mg} \cdot \mathrm{l}^{-1}$ IBA. The shoot length decreased with the increasing concentration of BAP. The highest root number (2.7) was formed on shoots cultured on the MS medium containing $0.5 \mathrm{mg} \cdot 1^{-1} \alpha$ naphthalene acetic acid, and the highest rhizome number (2.2) was formed on the medium with $0.5 \mathrm{mg} \cdot \mathrm{l}^{-1}$ BAP. In vitro rooted plantlets were able to survive and acclimatize in the greenhouse.
\end{abstract}

Key words: Alstroemeria, direct organogenesis, micropropagation

\section{INTRODUCTION}

Alstroemeria genus plants are rhizomatous monocotyledonous perennials belonging to the family Alstroemeriaceae that includes several ornamental species (Fay et al. 2006; Hoshino et al. 2006; Lee \& Han 2006). A number of cytologically stable homozygous lines were developed from Alstroemeria ligtu hybrid that was derived from a natural crossing between A. ligtu and A. ligtu ssp. simsii (Sprengel) (Robinson 1963), as a result of selection lasting many generations (Rustanius et al. 1991).

Alstroemeria was propagated formerly by rhizome division but this method is not efficient and involves a high risk of viral dissemination (Van Zaayen 1995). Therefore, in vitro propagation techniques based on rhizome multiplication in vitro have been developed (Gabryszewska \& Hempel 1985; Hakkaart \& Versluijs 1988; Van Zaayen et al. 1992; Bond \& Alderson 1993). However, the multiplication rate was still not satisfactory (Lin et al. 1998). Furthermore, flower pedicels and stem segments have been tested as initial explants but they showed a low response (Lin \& Monette 1987). Nodal leaf explants taken from in vitro grown seedlings were found to be a good starting material for Alstroemeria micropropagation as adventitious shoot formation was observed in the region between leaf and stem without callus formation (Lin et al. 1997). This method was recommended for propagation of existing cultivars (Lin et al. 1998). Use of leaves as initial explants may provide more explants for initiation and solve the problem of disinfection, because it is expected that aerial plant parts are less contaminated than underground parts (Lin et al. 1998).

Among the explants of monocotyledons used for the induction in vitro of regenerable cultures, leaf bases of young seedlings are the most easily available donor material (Gless et al. 1998). The objective of the present study was to develop in vitro regeneration method based on the first seed- 
ling leaves that can be used for mass propagation of Alstroemeria ligtu hybrid plants and genetic transformation via direct organogenesis.

\section{MATERIALS AND METHODS}

\section{Plant material}

\section{In vitro seed germination}

Alstroemeria ligtu hybrid seeds prepared by Dobies of Devon Company (www.dobies.co.uk) in November 2011 were used for the production of seedlings. A single commercial seed bag contained 25 seeds representing different colors. Overall, 600 seeds were used in the experiments.

The seeds were washed with tap water and sterilized in $70 \%$ ethanol (1 min), 3\% sodium hypochlorite solution (20 min) and then rinsed thrice with sterilized water. They were incubated in $250 \mathrm{ml}$ jars containing half-strength Murashige and Skoog (1962) - MS, supplemented with $1 \%$ sucrose, $0.7 \%$ agar; the $\mathrm{pH}$ was adjusted to 5.8 . Each culture jar contained eight seeds. The cultures were incubated for 1 week in a growth chamber $\left(21^{\circ} \mathrm{C}\right.$, 16 hours of light) and then transferred for stratification at $5 \pm 1{ }^{\circ} \mathrm{C}$ for 3 weeks. After stratification, the jars were again incubated in the growth chamber for 2 weeks. Seed germination was observed 6 weeks after sowing (Fig. 1. Stage 1).

\section{Experiment 1}

\section{Leaf base regeneration and shoot multiplication}

\section{Culture of leaf bases}

The bases of the 1-2 first seedling leaves, which were available 7-8 days after germination were used for the regeneration experiment. Fragments of bases about $1 \mathrm{~cm}$ long from randomly selected seedlings were excised (Fig. 1. Stage 1) and cultured on the media MS supplemented with different concentrations of N6-benzylaminopurine (BAP): $0,0.5,1,1.5$ or $2 \mathrm{mg} \cdot \mathrm{l}^{-1}$, and indole-3butyric acid (IBA): $0,0.1$ or $0.2 \mathrm{mg} \cdot \mathrm{l}^{-1}, 3 \%$ sucrose and solidified with $0.7 \%$ agar at $\mathrm{pH}$ 5.8. The cultures were incubated at $21 \pm 2{ }^{\circ} \mathrm{C}$ under 16 hours of light and 8 hours of darkness (Hutchinson et al. 2010).

\section{Bud formation and shoot multiplication}

After 2 weeks, the explants contained one to two shoots (about $2 \mathrm{~cm}$ long) and two or three buds regenerated from the area between the leaf base and stem tissue, without formation of callus. The explants were transferred to fresh media as above and subcultured every 3 weeks. Numbers of adventitious shoots and leaves and stem lengths were recorded after 4 and 8 weeks since initiation of experiment. Numbers of adventitious buds were recorded 8 weeks since initiation of experiment. They are presented as means per one initial explant.

\section{Experiment 2 \\ Rhizome induction and shoot rooting}

For rhizome induction, plantlets obtained in the first experiment (with three shoots 4-7 cm long and one or two adventitious buds) were transferred to new culture media containing $0,0.5$ or $1 \mathrm{mg} \cdot 1^{-1}$ BAP. For shoot rooting (SR), the plants were transferred to a rooting media containing MS medium supplemented with $0,0.5$ or $1 \mathrm{mg} \cdot 1^{-1} \alpha$-naphthalene acetic acid (NAA).

To induce rhizomes, plantlets were placed at $16 \pm 2{ }^{\circ} \mathrm{C}$ and 8 hours of fluorescent light/16 hours of darkness. Rooting was carried out at $18 \pm 2{ }^{\circ} \mathrm{C}$ and 16 hours of fluorescent light (Pierik et al. 1988). The rooting and rhizome induction were assessed 8-10 weeks after implantation of the plantlets; the number of rhizomes, and number and length of roots per plantlet were recorded.

\section{Acclimatization}

The regenerated plantlets with well-developed roots were transferred to a growth chamber and kept at $21{ }^{\circ} \mathrm{C}$ for 5-7 days. Agar attached to roots was removed and the plantlets were transferred to small pots containing an autoclaved substrate (mixture of perlite and peat 2:1, v/v). Microplants, which survived, were successively transferred to a greenhouse.

\section{Statistical analysis}

For in vitro shoot multiplication, an experiment was arranged in a completely randomized design. Each of the 15 treatments contained four experimental units with three replications. The experimental unit was a jar with one explant. Therefore, 12 explants consisted of an experimental treatment. For statistical analysis, data col- 
lected after 4 and 8 weeks since the beginning of the experiment were used.

The experiment on rooting and rhizome induction was set up in completely randomized design: three treatments with four experimental units and three replications.

The statistical analysis was done using the GLM procedure of SAS. Data were subjected to analysis of variance (ANOVA). The differences between the means were compared using Duncan's multiple range test $(\mathrm{p}<0.05)$.

\section{RESULTS}

\section{Bud formation and shoot multiplication}

Direct shoot formation was observed in the area adjacent to the region between the leaf and stem tissue, and no callus was formed. Growth regulators influenced shoot induction and bud formation on leaf bases (Table 1). Maximum shoot number was formed on culture medium containing $1 \mathrm{mg} \cdot \mathrm{l}^{-1}$ of BAP and $0.1 \mathrm{mg} \cdot \mathrm{l}^{-1}$ of IBA (four and six shoots per explant during 4 and 8 weeks of culture, respectively). On the medium containing $0.2 \mathrm{mg} \cdot \mathrm{l}^{-1} \mathrm{IBA}$ and $0 \mathrm{mg} \cdot \mathrm{l}^{-1} \mathrm{BAP}$, shoots were not formed (Table 1). Interaction of IBA and BAP in shoot formation was significant. Bud formation and shoot growth from leaf bases and stem tissue is shown in Fig. 1 Stage 2. The shoots (about $2 \mathrm{~cm}$ long) and bud induction was observed 15 days after cultivation in most of the tested media. In the medium with $1 \mathrm{mg} \cdot 1^{-1}$ BAP, 2.33 adventitious shoots per explant during 8 weeks were formed. An increase in BAP concentration within $0-1 \mathrm{mg} \cdot \mathrm{l}^{-1}$ caused an increase in shoot and bud number. Further increase of BAP concentration reduced the shoot number. IBA at $0.2 \mathrm{mg} \cdot l^{-1}$ suppressed bud formation. The highest number of induced adventitious buds was obtained in the medium containing $1 \mathrm{mg} \cdot 1^{-1}$ BAP and $0.1 \mathrm{mg} \cdot 1^{-1}$ IBA (3.66 bud per explant within 8 weeks). The highest number of adventitious shoots was obtained on the same medium -4.0 and 6.0 after 4 and 8 weeks respectively. Buds and shoots were not formed in the medium with $0.2 \mathrm{mg} \cdot \mathrm{l}^{-1} \mathrm{IBA}$ and $0 \mathrm{mg} \cdot \mathrm{l}^{-1} \mathrm{BAP}$.

\section{Shoot length}

Shoots length increased with the increasing IBA concentration at each concentration of BAP and decreased with increasing concentration of BAP at each concentration of IBA. Highest shoots - 11.4-11.9 cm - were formed in the media supplemented with 0.1 and $0.2 \mathrm{mg} \cdot \mathrm{l}^{-1} \mathrm{IBA}$ at zero and the lowest concentrations of BAP (Table 1).

\section{Leaf number}

The average number of leaves per explant was lowest in the media with no auxin at each concentration of BAP. The maximum number of leaves was formed in the medium containing $1 \mathrm{mg} \cdot 1^{-1}$ BAP at each concentration IBA. Maximum leaf number -7.33 and 10.66 leaves per explant was observed in the medium containing $1 \mathrm{mg} \cdot 1^{-1}$ BAP $+0.1 \mathrm{mg} \cdot \mathrm{l}^{-1}$ IBA after 4 and 8 weeks of culture, respectively (Table 1).

\section{Rhizome induction and shoot rooting}

After 4 weeks of culture on rhizome-inducing medium, the rhizome apex, which appeared at one side of the former enlarged shoot base, was wrapped by a scale leaf and looked like a shoot bud. This bud developed into a shoot with an enlarged base. After another 3-4 weeks, simultaneously new rhizomes developed on the shoot bases (Fig. 1 Stage 4 A, B). Rhizomes were not formed without BAP in the medium. More rhizomes were recorded on the medium containing $0.5 \mathrm{mg} \cdot \mathrm{l}^{-1}$ than $1 \mathrm{mg} \cdot 1^{-1}$ BAP (Table 2).

After 2-4 weeks, shoots formed roots in the root-inducing medium. Of 90 microshoots in the experiment, 60 formed roots. Roots were not formed without NAA in the medium. More roots 2.75 per shoot - appeared on the medium containing $0.5 \mathrm{mg} \cdot \mathrm{l}^{-1} \mathrm{NAA}$ than at NAA $1 \mathrm{mg} \cdot \mathrm{l}^{-1}(1.75)$, but these roots were longer (Table 2).

\section{Acclimatization}

Some of the 60 rooted microshoots turned brown and died soon after planting in pots but 48 survived for 15 days and continued growth in the greenhouse. 
Stage 1

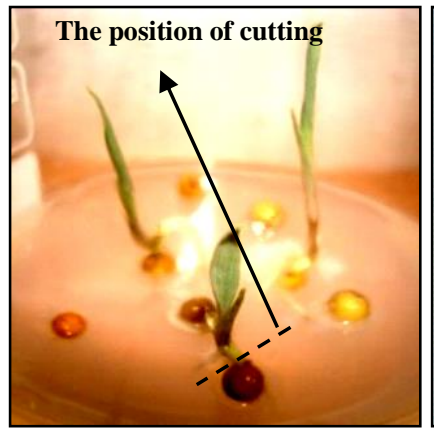

Stage 2.

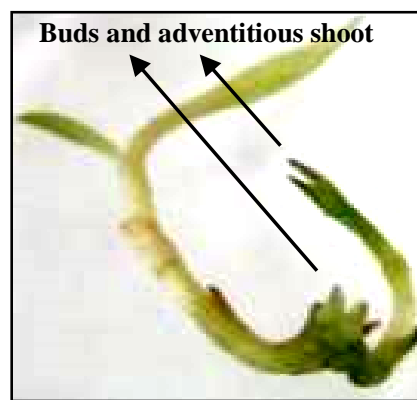

Stage 3. A

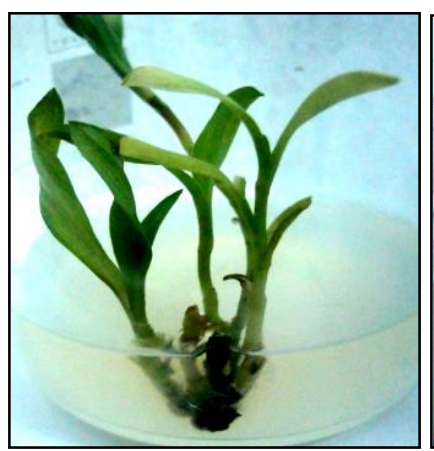

Stage 3. B

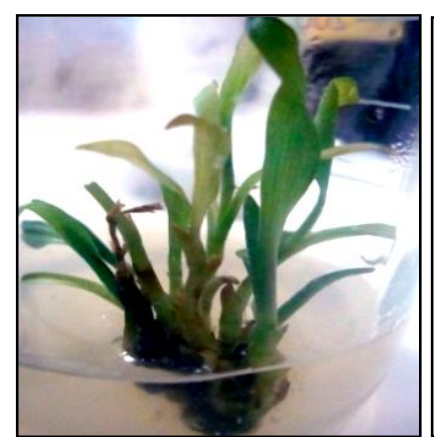

Stage 4. A

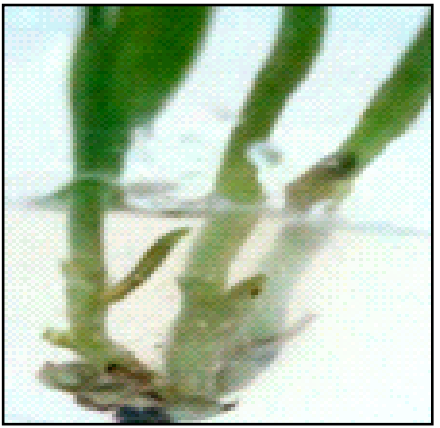

Stage 4. B

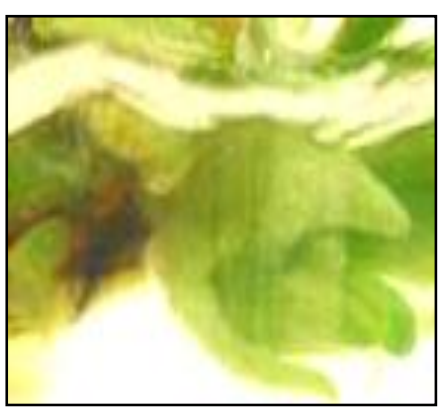

Stage 5.

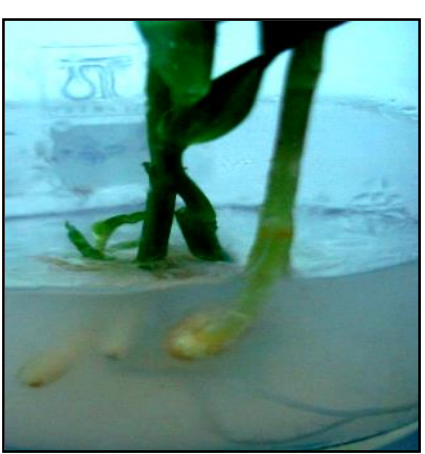

Stage 6.

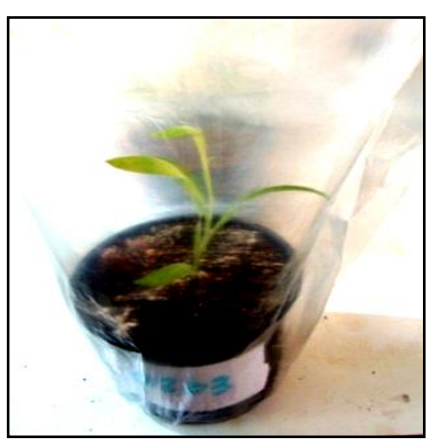

Stage 1. Seed germination (6 weeks)

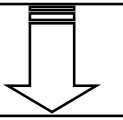

Stage 2. Basal leaf regeneration (2 weeks)

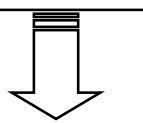

Stage 3. Subculturing originated adventitious shoots after 4 weeks (A) (4 shoots per explant) and 8 weeks (B) $(6$ shoots per explant) on MS medium supplemented with $1 \mathrm{mg} \cdot \mathrm{l}^{-1}$ of BAP and $0.1 \mathrm{mg} \cdot 1^{-1}$ IBA

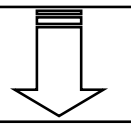

Stage 4 A, B. Rhizome formation (2.25 rhizome/ plantlet on MS $+0.5 \mathrm{mg} \cdot 1^{-1}$ of BAP). (7-8 weeks)

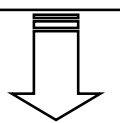

Stage 5. Rooting of plantlets on MS $+0.5 \mathrm{mg} \cdot \mathrm{l}^{-1}$ of NAA (2.75 roots per plantlet) (4 weeks)

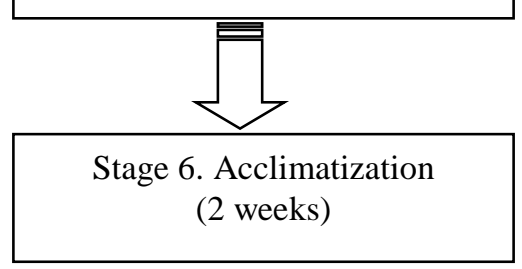

Fig. 1. Different stages of direct organogenesis from bases of the first seedling leaves of Alstroemeria ligtu hybrid. Stage 1: In vitro grown seedlings about 7-8 days old; Stage 2: Buds and shoots regenerated from the area between the leaf base and stem tissue after 2 weeks on MS medium supplemented with $1 \mathrm{mg} \cdot \mathrm{l}^{-1}$ of BAP and $0.1 \mathrm{mg} \cdot \mathrm{l}^{-1}$ IBA; Stage 3: A. Shoot multiplication after 4 weeks (4 shoots per explant); B. 8 weeks (6 shoots per explant) on MS medium supplemented with $1 \mathrm{mg} \cdot 1^{-1}$ of BAP and $0.1 \mathrm{mg} \cdot 1^{-1}$ IBA; Stage 4: A. Rhizome formation (2.25 rhizome/plantlet on MS $+0.5 \mathrm{mg} \cdot \mathrm{l}^{-1}$ of BAP); B. A rhizome apex appeared at one side of the shoot base (7-8 weeks); Stage 5: Rooting of plantlets (2.75 roots per plantlet on MS $+0.5 \mathrm{mg} \cdot \mathrm{l}^{-1}$ of NAA) with rhizome and aerial shoots (4 weeks); Stage 6: Plantlets acclimatized in greenhouse 
Table 1. Effect of N6-benzylaminopurine (BAP), indole-3-butyric acid (IBA) and their interaction on the number of adventitious buds and shoots and shoot growth during 4 and 8 weeks of culture

\begin{tabular}{|c|c|c|c|c|c|c|c|c|}
\hline \multirow{2}{*}{$\begin{array}{c}\text { IBA } \\
\left(\mathrm{mg} \cdot \mathrm{l}^{-1}\right)\end{array}$} & \multirow{2}{*}{$\begin{array}{c}\text { BAP } \\
\left(\mathrm{mg} \cdot l^{-1}\right)\end{array}$} & \multirow{2}{*}{$\begin{array}{c}\begin{array}{c}\text { Number of } \\
\text { adventitious } \\
\text { buds }\end{array} \\
\begin{array}{c}\text { 8-week } \\
\text { cultures }\end{array} \\
\end{array}$} & \multicolumn{2}{|c|}{ Number of adventitious shoots } & \multicolumn{2}{|c|}{ Shoot length $(\mathrm{cm})$} & \multicolumn{2}{|c|}{ Number of leaves } \\
\hline & & & $\begin{array}{l}\text { 4-week } \\
\text { cultures }\end{array}$ & $\begin{array}{c}8 \text {-week } \\
\text { cultures } \\
\end{array}$ & $\begin{array}{l}\text { 4-week } \\
\text { cultures }\end{array}$ & $\begin{array}{l}\text { 8-week } \\
\text { cultures }\end{array}$ & $\begin{array}{l}\text { 4-week } \\
\text { cultures }\end{array}$ & $\begin{array}{c}\text { 8-week } \\
\text { cultures }\end{array}$ \\
\hline 0 & 0 & $0.33 \pm 0.33^{\text {ef }}$ & $0.33 \pm 0.33^{\text {ef }}$ & $0.33 \pm 0.33^{\mathrm{fg}}$ & $5.7 \pm 0.17^{\mathrm{de}}$ & $8.4 \pm 0.31^{\mathrm{de}}$ & $2.66 \pm 0.3^{\mathrm{e}}$ & $4.33 \pm 0.3^{\mathrm{f}}$ \\
\hline 0 & 0.5 & $1 \pm 0.0^{\text {cdef }}$ & $1.33 \pm 0.33^{\mathrm{bcd}}$ & $1.33 \pm 0.33^{\text {cdef }}$ & $5.4 \pm 0.12^{\mathrm{ef}}$ & $7.9 \pm 0.23^{\mathrm{e}}$ & $3.66 \pm 0.3^{\mathrm{e}}$ & $5.66 \pm 0.3^{\mathrm{ef}}$ \\
\hline 0 & 1 & $2 \pm 0.0^{\mathrm{bc}}$ & $2 \pm 0.0^{\mathrm{b}}$ & $2.33 \pm 0.33^{\mathrm{bc}}$ & $4.4 \pm 0.17^{\mathrm{g}}$ & $6.6 \pm 0.21^{\mathrm{fg}}$ & $3.66 \pm 0.3^{\mathrm{e}}$ & $6.33 \pm 0.3^{\mathrm{def}}$ \\
\hline 0 & 1.5 & $1.33 \pm 0.33^{\text {cde }}$ & $1 \pm 0.0^{\text {cde }}$ & $1.33 \pm 0.33^{\text {cdef }}$ & $3.9 \pm 0.06^{\mathrm{h}}$ & $5.9 \pm 0.21^{\mathrm{gh}}$ & $3 \pm 0.0^{\mathrm{e}}$ & $5.33 \pm 0.9^{\mathrm{ef}}$ \\
\hline 0 & 2 & $1 \pm 0.0^{\text {cdef }}$ & $1.33 \pm 0.33^{\text {bcd }}$ & $1.66 \pm 0.33^{\text {bcde }}$ & $3.7 \pm 0.15^{\mathrm{h}}$ & $5.6 \pm 0.17^{\mathrm{h}}$ & $3 \pm 0.6^{\mathrm{e}}$ & $5.33 \pm 0.3^{\mathrm{ef}}$ \\
\hline 0.1 & 0 & $0.33 \pm 0.33^{\text {ef }}$ & $0.66 \pm 0.33^{\mathrm{def}}$ & $0.66 \pm 0.33^{\mathrm{efg}}$ & $8.4 \pm 0.21^{\mathrm{b}}$ & $11.66 \pm 0.2^{\mathrm{a}}$ & $5.33 \pm 0.3^{\mathrm{cd}}$ & $7.66 \pm 0.9^{\text {bcde }}$ \\
\hline 0.1 & 0.5 & $2 \pm 0.0^{\mathrm{bc}}$ & $2 \pm 0.0^{\mathrm{b}}$ & $2.33 \pm 0.33^{\mathrm{bc}}$ & $7.3 \pm 0.23^{\mathrm{c}}$ & $10.55 \pm 0.12^{\mathrm{b}}$ & $6.66 \pm 0.7^{\mathrm{ab}}$ & $9.33 \pm 1.2^{\mathrm{ab}}$ \\
\hline 0.1 & 1 & $3.66 \pm 0.33^{\mathrm{a}}$ & $4 \pm 0.0^{\mathrm{a}}$ & $6 \pm 0.57^{\mathrm{a}}$ & $7 \pm 0.06^{c}$ & $10.33 \pm 0.33^{b c}$ & $7.33 \pm 0.3^{\mathrm{a}}$ & $10.66 \pm 0.7^{\mathrm{a}}$ \\
\hline 0.1 & 1.5 & $2.66 \pm 0.33^{\mathrm{b}}$ & $2 \pm 0.0^{\mathrm{b}}$ & $2.66 \pm 0.33^{\mathrm{bc}}$ & $5.7 \pm 0.17^{\mathrm{de}}$ & $8.7 \pm 0.38^{\mathrm{d}}$ & $5.66 \pm 0.3^{\mathrm{bcd}}$ & $8.33 \pm 0.9^{\mathrm{abcd}}$ \\
\hline 0.1 & 2 & $1.66 \pm 0.33^{\mathrm{bcd}}$ & $1.66 \pm 0.33^{\mathrm{bc}}$ & $2 \pm 0.0^{\mathrm{bcd}}$ & $4.6 \pm 0.12^{\mathrm{g}}$ & $7 \pm 1.0^{\mathrm{f}}$ & $5 \pm 0.0^{\mathrm{d}}$ & $6.66 \pm 0.7^{\text {cdef }}$ \\
\hline 0.2 & 0 & $0 \pm 0.0^{\mathrm{f}}$ & $0 \pm 0.0^{\mathrm{f}}$ & $0 \pm 0.0^{\mathrm{g}}$ & $8.9 \pm 0.10^{\mathrm{a}}$ & $11.9 \pm 0.44^{\mathrm{a}}$ & $5 \pm 0.6^{\mathrm{d}}$ & $6.66 \pm 0.7^{\text {cdef }}$ \\
\hline 0.2 & 0.5 & $0.33 \pm 0.33^{\mathrm{ef}}$ & $0.66 \pm 0.33^{\mathrm{def}}$ & $0.66 \pm 0.33^{\text {efg }}$ & $8.3 \pm 0.17^{b}$ & $11.4 \pm 0.15^{\mathrm{a}}$ & $6.33 \pm 0.3^{\mathrm{abc}}$ & $8.33 \pm 0.9^{\mathrm{abcd}}$ \\
\hline 0.2 & 1 & $1.33 \pm 0.33^{\text {cde }}$ & $1.33 \pm 0.33^{\mathrm{bcd}}$ & $1.66 \pm 0.33^{\text {bcde }}$ & $7.2 \pm 0.12^{\mathrm{c}}$ & $10.5 \pm 0.23^{\mathrm{b}}$ & $6.66 \pm 0.3^{\mathrm{ab}}$ & $10.33 \pm 0.9^{\mathrm{a}}$ \\
\hline 0.2 & 1.5 & $0.66 \pm 0.33^{\text {def }}$ & $0.66 \pm 0.33^{\mathrm{def}}$ & $1 \pm 0.0^{\text {defg }}$ & $6.1 \pm 0.20^{\mathrm{d}}$ & $9.7 \pm 0.15^{\mathrm{c}}$ & $6.33 \pm 0.3^{\mathrm{abc}}$ & $9 \pm 0.6^{\mathrm{abc}}$ \\
\hline 0.2 & 2 & $0.66 \pm 0.33^{\mathrm{def}}$ & $0.66 \pm 0.33^{\mathrm{def}}$ & $0.66 \pm 0.33^{\mathrm{efg}}$ & $5.2 \pm 0.12^{\mathrm{f}}$ & $8.4 \pm 0.31^{\text {de }}$ & $5 \pm 0.3^{\mathrm{d}}$ & $7.66 \pm 0.6^{\text {bcde }}$ \\
\hline
\end{tabular}

* The values are the mean \pm SE $(n=3)$, and the means in a column followed by the same letter are not significantly different according to Duncan's test $(\mathrm{p}=5 \%)$.

Table 2. Effects of N6-Benzylaminopurine (BAP) concentration on rhizome induction and naphthalene acetic acid (NAA) on the rooting of Alstroemeria plants

\begin{tabular}{ccccc}
\hline BAP $\left(\mathrm{mg} \cdot 1^{-1}\right)$ & Number of rhizomes & NAA $\left(\mathrm{mg} \cdot \mathrm{l}^{-1}\right)$ & Number of roots & Root length $(\mathrm{cm})$ \\
\hline 0 & $0 \pm 0.0^{\mathrm{c}}$ & 0 & $0 \pm 0.25^{\mathrm{c}}$ & $0 \pm 0.0^{\mathrm{c}}$ \\
0.5 & $2.25 \pm 0.25^{\mathrm{a}}$ & 0.5 & $2.75 \pm 0.25^{\mathrm{b}}$ & $2.65 \pm 0.202^{\mathrm{b}}$ \\
1 & $1.75 \pm 0.25^{\mathrm{b}}$ & 1 & $1.75 \pm 0.25^{\mathrm{a}}$ & $3.075 \pm 0.095^{\mathrm{a}}$ \\
\hline
\end{tabular}

* The values are the mean \pm SE $(n=3)$, and the means in a column followed by the same letter are not significantly different according to Duncan's test $(\mathrm{p}=5 \%)$.

\section{DISCUSSION}

Most published methods on the micropropagation of Alstroemeria are based on shoot regeneration from rhizome apices (Gabryszewska \& Hempel 1985; Lin \& Monette 1987; Pedersen \& Brandt 1992; Pedersen et al. 1996; Kristiansen et al. 1999; Chiari \& Bridgen 2000). The problem accompanying this method concerns scarcity of initial explants and their heavier contamination. Explants taken from aerial shoots are easier to sterilize than underground rhizomes (Pierik et al. 1988).
For effective propagation, concentrations of growth regulators, especially cytokinins and auxins are crucial (Kalimuthu et al. 2007). Pedraza-Santos et al. (2006) demonstrated that the addition of $1 \mathrm{mg} \cdot l^{-1}$ BAP to the MS basal culture medium caused formation of up to 9.0 shoots per explant. In our experiment, an increase in BAP concentration from 0 to $1 \mathrm{mg} \cdot l^{-1}$ stimulated the increase of adventitious shoots number. The proportion of BAP to IBA 10:1, at BAP 1 was most beneficial for number of shoots, their length and leaves number. Hutchinson et al. (2010) obtained similar results. The shoots were induced directly, without a callus 
phase, from newly formed adventitious buds (Nakamura \& Hattori 1995; Lin et al. 1998). A similar type of regeneration was observed in our experiments. The shoots and buds were regenerated as adventitious ones, because no pre-existing axillary buds or bud-primordia were found. The adventitious buds are induced from individual epidermic cells of the leaf axil tissues, and it seems that the cells within leaf axils exhibit a high potential for regeneration (Lin et al. 1997, 1998). Pierik et al. (1988) and Lin et al. (1997, 1998, 2000b) found that supplementing the culture medium with $0.5 \mathrm{mg} \cdot \mathrm{l}^{-1}$ BAP caused maximum proliferation rates in different explants of Alstroemeria (seed embryos, rhizome apices and leaf segments). In the present study, concentrations of BAP higher than $1.0 \mathrm{mg} \cdot 1^{-1}$ caused a reduction in shoot number, similar to that reported by Pierik et al. (1988). In the previous studies on Alstroemeria in tissue cultures, the use of BAP was effective for plant regeneration in most cases (Kim et al. 2006; Lin et al. 1997, 1998, 2000a, b; Pedraza-Santos et al. 2006). However, in our study, BAP combined with IBA was effective for regeneration of Alstroemeria. Thus, BAP plays an important role in the regeneration of Alstroemeria.

Cytokinins cause shoot induction by stimulating cell division and decreasing apical dominance (George et al. 2008). The highest average length $(11.9 \mathrm{~cm})$ of shoots was recorded after 8 weeks at $0.2 \mathrm{mg} \cdot \mathrm{l}^{-1}$ IBA. This result directs our attention to the well known role of auxins in the elongation of the plant cells (Asghari et al. 2012). It is commonly known that auxin induces a number of responses including cell division, cell enlargement, and synthesis of proteins and nucleic acids that are concomitants in auxin-induced growth and in changes in plant cell wall plasticity. Auxin causes also an icrease in the apical dominance, which is essential in processes of growth and elongation of shoots (George et al. 2008).

A higher SM index on BAP containing media, however, was concomitant with a marked reduction in shoot length. In our study, shoot length was reduced with increasing concentration of BAP at each concentration of IBA.
In this experiment, the shoots regeneration always occurred directly from the leaf base without forming callus. Hansena and Wright (1999) reported that there is a risk of morphological abnormalities and sterility in plants regenerated from calli in vitro. In our experiment, shoots regenerated directly without callus phase, so a risk of genetic variation was low. Regenerated shoots formed rhizomes when subcultured in the medium containing BAP within 2 months. Thus, the regeneration cycle was completed within 4 to 5 months. The highest number of rhizomes, 2.25 per shoot was obtained in the presence of $0.5 \mathrm{mg} \cdot 1^{-1}$ BAP. Bond and Alderson (1993) and Lin et al. (2000b) found that the number of shoots often was not associated with the number of rhizomes, which was confirmed in our experiment, where the number of shoots per explant was not equal to the number of lateral rhizomes.

For in vitro root formation of Alstroemeria, an MS-based medium with 3-4\% sucrose, and $0.37 \mathrm{mg} \cdot \mathrm{l}^{-1}$ NAA was used (Gabryszewska \& Hempel 1985; Pierik et al. 1988; Pedersen et al. 1996). Lin and Monette (1987) found that effect of IBA in concentrations of 0.03 and $0.3 \mathrm{mg} \cdot \mathrm{l}^{-1}$ on root number was not significant. NAA has been found to be the most effective auxin for root formation (Gabryszewska \& Hempel 1985; Pierik et al. 1988). The positive effects of NAA and the negative effects of BAP on root formation were reported for Alstroemeria (Gabryszewska \& Hempel 1985; Kristiansen et al. 1999). The maximum number of roots (2.75) per shoot was observed in the medium supplemented with $0.5 \mathrm{mg} \cdot \mathrm{l}^{-1} \mathrm{NAA}$. The highest number of long roots was noticed in the media supplemented with $1 \mathrm{mg} \cdot \mathrm{l}^{-1} \mathrm{NAA}$ (3.07) whereas with $0.5 \mathrm{mg} \cdot \mathrm{l}^{-1}$ NAA, 2.65 roots per shoot were formed. Hakkaart and Versluijs (1988) reported that the in vitro rooting of Alstroemeria could be induced without any plant hormones. However, other researchers have obtained best rooting rates in the presence of NAA (Gabryszewska \& Hempel 1985; Pierik et al. 1988; Pedersen et al. 1996; Kristiansen et al. 1999).

Gabryszewska and Hempel (1985) demonstrated that the addition of BAP to the growing medium stimulated rhizome branching. Similar results were obtained by Pierik et al. (1988). In our 
experiment, concentration of $5 \mathrm{mg} \cdot \mathrm{l}^{-1} \mathrm{BA}$ was sufficient to induce rhizome branching.

Thus, in this study, the best culture medium for adventitious shoot regeneration from seedling leaves of Alstroemeria ligtu hybrid was the medium containing $1 \mathrm{mg} \cdot \mathrm{l}^{-1} \mathrm{BAP}$ and $0.1 \mathrm{mg} \cdot \mathrm{l}^{-1} \mathrm{IBA}$ with the average production of six shoots within 8 weeks. The most effective for rhizome induction was the medium containing $0.5 \mathrm{mg} \cdot \mathrm{l}^{-1}$ BAP $(2.25$ rhizomes) and for root induction medium with $0.5 \mathrm{mg} \cdot \mathrm{l}^{-1} \mathrm{NAA}$ (2.75 roots from a shoot).

\section{REFERENCES}

Asghari F., Hossienil B., Hassani A., Shirzad H. 2012. Effect of explants source and different hormonal combinations on direct regeneration of basil plants (Ocimum basilicum L.). Aust. J. Agric. Eng. 3: 1217.

Bond S., Alderson P.G. 1993. The influence of apical dominance on in vitro multiplication of the rhizome of Alstroemeria. J. Hort. Sci. 68: 905-910.

Chiari A., Bridgen M.P. 2000. Rhizome splitting: a new micropropagation technique to increase in vitro propagule yield in Alstroemeria. Plant Cell Tiss. Org. Cult. 62: 39-46.

Fay M.F., Chase M.W., Ronsted N., Devey D.S., PillonY., Pires J.C., Petersen G., Seberg O., Davis J.I. 2006. Phylogenetics of Liliales: summarized evidence from combined analyses of five plastid and one mitochondrial loci. Ranc. Sant. An. Bot. Gard. 22: 559-565.

Gabryszewska E., Hempel M. 1985. The influence of cytokinins and auxins on Alstroemeria in tissue culture. Acta Hort. 167: 295-300.

George E.F., Hall M.A., Klerk G.J.D. 2008. Plant Propagation by Tissue Culture. 3rd Edition, Springer, pp. 175-204. DOI 10.1007/978-1-4020-5005-3.

Gless C., Lörz H., Jähne-Gärtner A. 1998. Establishment of a highly efficient regeneration system from leaf base segments of oat (Avena sativa L.). Plant Cell Rep. 17: 441-445. http://dx.doi.org/10.1007/s002990050422

Hakkaart F.A., Versluijs J.M.A. 1988. Virus elimination by meristem tip culture from arrange of Alstroemeria cultivars. Neth. Plant Pathol. 94: 49-56.

Hansena G., Wright M.S. 1999. Recent advances in the transformation of plants. Trends Plant Sci. 4: 226231. DOI 10.1016/S1360-1385(99)01412-0.

Hoshino Y., Murata N., Shinoda K. 2006. Isolation of individual egg cells and zygotes in Alstroemeria followed by manual selection with a microcapillary-connected micropump. Ann Bot. 97: 11391144. DOI 10.1093/aob/mcl072.

Hutchinson M.J., Onamu R., Kipkosgei L., Obukosia S.D. 2010. Effect of thidiazuron, NAA and BAP on in vitro propagation of Alstroemeria aurantiaca cv. 'Rosita' from shoot tip explants. J. Agri. Sci. Tech. 12: 60-69.

Kalimuthu K., Paulsamy S., Senthilkumar R., Sathya M. 2007. In vitro propagation of the biodiesel plant Jatropha curcas L. Plant Tiss. Cult. Biotechnol. 17: 137-147. http://dx.doi.org/10.3329/ ptcb.v17i2.3234

Kim J.B., Raemakers C.J.J.M., Jacobsen E., Visser R.G.F. 2006. Efficient somatic embryogenesis from leaves with axil tissue in Alstroemeria. Plant Cell Tiss. Org. Cult. 86: 233-238. DOI: 10.1007/s11240-006-9110-6.

Kristiansen K., Ørnstrup H., Brandt B. 1999. In vitro PPFD and media composition affect both in and $e x$ vitro performance of Alstroemeria Butterflyhybrids. Plant Cell Tiss. Org. Cult. 56: 145-153.

Lee J.H., Han T.H. 2006. Identification of parental species of the Alstroemeria cv. 'Jubilee' using AFLP marker technique. Sci. Hort. 111: 63-67. DOI: 10.1016/j.scienta.2006.08.001.

Lin W.C., Monette P.L. 1987. In vitro propagation of Alstroemeria "Alsaan". Plant Cell Tiss. Org. Cult. 9: 29-35.

Lin H.S., De Jeu M.J., Jacobsen E. 1997. Direct shoot regeneration from excised leaf explant of in vitro grown seedlings of Alstroemeria L. Plant Cell Rep. 16: 770-774. DOI: 10.1007/s002990050317.

Lin H.S., De Jeu M.J., Jacobsen E. 1998. Formation of shoots from leaf axils of Alstroemeria: the effect of position on the stem. Plant Cell Tiss. Org. Cult. 52: $165-169$.

Lin H.S., De Jeu M.J., Jacobsen E. 2000a. Development of a plant regeneration system based on friable embryogenic callus in the ornamental Alstroemeria. Plant Cell Rep. 19: 529-534. DOI: 10.1007/s002990050768.

Lin H.S., De Jeu M.J., Jacobsen E. 2000b. The application of leafy explant micropropagation protocol in enhancing the multiplication efficiency of $\mathrm{Al}$ stroemeria. Sci. Hort. 85: 307-318. DOI: 10.1016/S0304-4238(00)00125-4.

Monette P.L. 1992. Micropropagation of Inca Lily (Alstroemeria spp.). In: Bajaj Y.P.S. (Ed.), Biotechnology in Agriculture and Forestry, Vol. 20, HighTech and Micropropagation IV, pp. 1-18. 
Murashige T., Skoog F. 1962. A revised medium for rapid growth and bioassays with tobacco tissue cultures. Physiol. Plant. 15: 473-496.

Pedersen C., Brandt K. 1992. A method for disinfection of underground rhizome tips of Alstroemeria and Heliconia. Acta Hort. 325: 499-504.

Pedersen C., Hansen C.W., Brandt K., Kristiansen K. 1996. Alstroemeria plantlets can be induced to flowering by cold treatment during in vitro culture. Sci. Hort. 66: 217-228. DOI: 10.1016/S03044238(96)00917-X.

Pedraza-Santos M.E., López-Peralta M.C., González V.A., Engleman-Clark E.M., Sánchez-García P. 2006. In vitro regeneration of Alstroemeria cv.'Yellow King' by direct organogenesis. Plant Cell Tiss. Org. Cult. 184: 189-198. DOI: 10.1007/s11240-005-9020-z.

Pierik R.L.M., Van Voorst A., Booy G.,Van Acker C.A.M., Lelivelt C.L.C., De Wit J.C. 1988. Vegetative propagation of Alstroemeria hybrids in vitro. Acta Hort. 226: 81-89.
Podwyszynska M., Gabryszewska E., Przybyla A. 1998. Effect of growth retardants, cytokinins and auxins on the multiplication and rooting in vitro of $A l$ stroemeria $\times$ hybrida 'Juanita'. Acta Agron. 51: 23-31. DOI: 10.5586/aa.1998.003.

Robinson G.W. 1963. Alstroemeria. J. Roy. Hortic. Soc. 88: 490-494.

Rustanius P., Hang A., Hughes H.G., Tsuchiya T. 1991. Chromosome analysis of Alstroemeria ligtu hybrids. Hort Sci. 26 (7): 902-904.

SAS Institute 2002. SAS/STAT User's Guide Release 9. Cary, NC, USA.

Van Zaayen A. 1995. Alstroemeria. In: Loebenstein G., Lawson R.H., Brunt A.A. (Eds.) Virus and Viruslike Diseases of Bulbs and Flower Crops, Wiley Publishers, Chichester, UK, pp. 237-249.

Van Zaayen C., Van E., Versluijs J.M.A. 1992. Production of high quality, healthy ornamental crops through meristem culture. Acta Bot. Neerl. 41: 425-433. 